\title{
Utilization of Industrial Wastes for Improving Geotechnical Properties of Collapsible Soil
}

\author{
Ashraf K. Nazir ${ }^{1}$, Ahmed M. Nasr ${ }^{2}$, Mona A. Darweesh ${ }^{3}$, Mariem M. Abbas ${ }^{4}$ \\ ${ }^{1}$ Prof. of geotechnical Engineering, Faculty of Engineering/ Tanta University, Tanta, Egypt \\ ${ }^{2}$ Prof. of geotechnical Engineering, Tanta University/ Tanta, Egypt \\ ${ }^{3}$ Prof. of chemical Engineering, Faculty of Engineering, Tanta University/ Tanta, Egypt. \\ ${ }^{4}$ M. SC. Student, Faculty of Engineering, Tanta University/ Tanta, Egypt \\ Email: ${ }^{1}$ Ashraf.Nazir@f-eng.tanta.edu.eg, ${ }^{2}$ Ahmed.nasr@f-eng.tanta.edu.eg, ${ }^{3}$ Mona.darwish@f-eng.tanta.edu.eg, ${ }^{4}$ Mariemmagdy628@gmail.com
}

\begin{abstract}
At the present time the disposal of industrial wastes has become a challenge for most countries. This research aims to study the effect of mixing the industrial textile sludge on geotechnical properties of collapsible soil. The experimental program studies the effect of textile wastes on Atterberg limits, collapse potential, compaction, CBR, and shear strength parameters. The percentages of textile wastes mixed with soil are $4,8,12,16,20$, and $24 \%$. The results indicated that the collapse potential of untreated soil is significantly decreased from about $11 \%$ to $2.6 \%$ at $24 \%$ of textile sludge. Shear test results show an increase in cohesion and decrease in the internal friction angle. For Atterberg limits there was an increase in liquid limit. For Compaction results, it is noticed a decrease in maximum dry density and an increase in optimum moisture content. CBR values for all samples indicates the suitability of using soil and soil-sludge mixtures only in subgrade layer of pavement. It was found that the reuse of textile sludge with collapsible soils considers an economic method to improve the physical and mechanical properties of the soil, in addition, it could be considered as sustainable management of textile sludge which leads to a reduction in the consumption of natural resources and preserves the surrounding environment through decreasing the retention of these wastes to a minimum.
\end{abstract}

Index terms: Industrial textile sludge, Collapsible soil, Collapse potential, $\mathrm{CBR}$

\section{INTRODUCTION}

Collapsible soils are defined as unsaturated soils susceptible to a large loss in volume upon wetting under the application of loads or not [1]. In Egypt, collapsible soils located within the northern portion of the western desert especially at Borg ElArab region, and also located near Cairo city at Six-of-October, and Tenth-of-Ramadan district [2]. Several treatment methods have been done for enhancing the properties of collapsible soil, either by adopting mechanical modification which mainly depends on rearranging soil particles through compaction or chemical alteration by reducing collapsibility through the interaction between soil and stabilizer [3, 4]. Soil chemical stabilization by cement, lime, and synthesized chemicals/fibers cause cracks in the fine-grained soils which leads to failure of the soil and subsequent failure of the structures. Thus, it has been a must to explore an alternative soil stabilizer such as sustainable materials which can be defined as an industrial waste like (rice ash, cement kiln dust, fly ash, sewage sludge, paper sludge, and textile sludge). The process of sustainability in our field can be defined as a periodic process of extracting minerals from nature by a human for industrial activities and giving it back as industrial by-products to be reused in soil stabilization for enhancement the undesirable geotechnical properties [5].Textile sludge is one of the sustainable materials that produced from the wastewater of textile industry, with the rapid increase of sludge around the world it became urgent to find cost efficient way to reduce and reuse sludge, a lot of researches concerned with the reuse of textile sludge in many applications in civil engineering, such as manufacture of clay bricks [6], as an additives in concrete [7], manufacture of ceramic bricks [8], and as a sub-grade material in the roadway [9]. Textile sludge also used as a fertilizer in agriculture field and in energy production of biogas [10]. It is obvious that a lot of researches have been more receptive to the application of textile sludge in different fields, however, there are limited studies in reusing of textile sludge in the geotechnical field.This research aims to study the effect of textile sludge as an additive to improve the geotechnical properties of collapsible soil.

\section{MATERIALS AND METHODS}

\section{A. Collapsible soil}

The soil samples were collected from Borg EL-Arab area $62 \mathrm{Km}$ west of Alexandria city, north of Egypt. Soil was kept in the oven with the temperature $105 \pm 5$ for 24 hours, then broken manually into smaller particles using the hammer and passed through sieve \#40, the particle size distribution curve is shown in Fig. 1, while the physical properties of soil are illustrated in Table 1

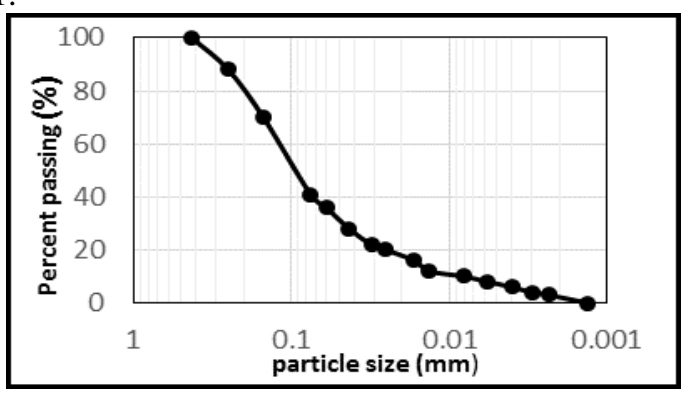

Fig. 1. Grain size distribution of collapsible soil

Table 1. Physical properties of collapsible soil

\begin{tabular}{|c|c|c|c|}
\hline \multicolumn{4}{|c|}{ Physical properties of soil } \\
\hline USCS & SM & $\mathrm{Cu}$ & 15.625 \\
\hline ASSHTO & $\mathrm{A}-4$ & $\mathrm{Cc}$ & 2.304 \\
\hline Gs & 2.7 & D 10 & .008 \\
\hline Sand & $59.3 \%$ & L.L & $30 \%$ \\
\hline Silt & $31.7 \%$ & P.L & $\mathrm{NP}$ \\
\hline Clay & $9 \%$ & P.I & $\mathrm{NP}$ \\
\hline O.M.C & $12.27 \%$ & M.D.D & $19 \mathrm{KN} / \mathrm{m} 3$ \\
\hline
\end{tabular}




\section{B. Textile sludge}

The textile sludge (T.S) was obtained from a textile factory located in EL-Mahala El-Kobra, Tanta, Egypt. The sludge has a high moisture content so it takes 3 days in the oven to get completely dry, after that the dry textile sludge Fig. 2a was crushed and passed through sieve \#40 Fig. 2b. Textile sludge was mixed by weight with the collapsible soil at different percentages: $4 \%, 8 \%, 12 \%, 16 \%, 20 \%$, and $24 \%$. The mixing process was done manually, and care was taken to obtain a homogeneous mixture at each percentage. The concentration of heavy metals in textile sludge was measured using an Inductivity Coupled Plasma ICP (Thermo Scientific ${ }^{\mathrm{TM}} 158$ ICAPTM 7000 Plus Series ICP-OES), the concentration values considered to be safe for use in soil compared with the values recommended by the regulations as shown in Table .2 [11]. ICP test also shows in Table 2, the concentration of other minerals existing in textile sludge.

The Energy-dispersive X-ray spectroscopy (EDAX) was carried out on textile sludge Fig. 3. Elemental analysis of textile sludge shows that oxygen $(\mathrm{O})$ and carbon $(\mathrm{C})$ are the main components of textile sludge with additional high peaks of silicon $(\mathrm{Si})$ followed by aluminum $(\mathrm{Al})$, magnesium $(\mathrm{Mg})$, calcium $(\mathrm{Ca})$, iron $(\mathrm{Fe})$, the presence of such elements plus the presence of high oxygen content could refer to the presence of the following oxides $\left(\mathrm{SiO}_{2}, \mathrm{Al}_{2} \mathrm{O}_{3}, \mathrm{MgO}, \mathrm{CaO}\right.$, and $\left.\mathrm{Fe}_{2} \mathrm{O}_{3}\right)$ which are the main oxides to form a pozzolanic reaction [12]. EDAX result of textile sludge also indicates traces of certain elements such as $(\mathrm{Na}, \mathrm{K}, \mathrm{Cl}, \mathrm{Ti}, \mathrm{Cu}, \mathrm{P}$, and $\mathrm{Zn})$
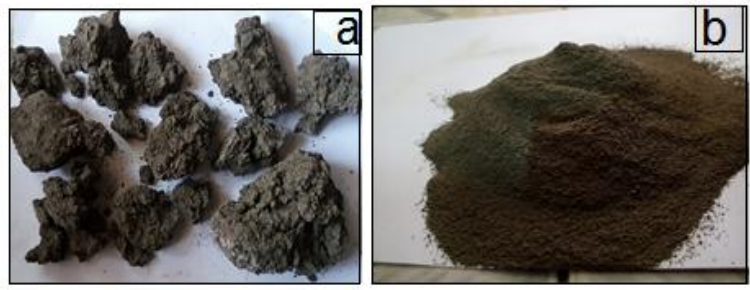

Fig. 2 Textile sludge: (a) before crushing, (b) after crushing and sieving

Table 2. Maximum concentrations values of heavy metals in sludge to be used in soil

\begin{tabular}{|c|c|c|c|c|c|c|}
\hline \multirow{2}{*}{ 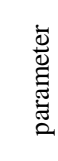 } & \multicolumn{4}{|c|}{$\begin{array}{c}\text { Maximum values } \\
\text { (mg/kg of dry matter) }\end{array}$} & \multirow{2}{*}{\multicolumn{2}{|c|}{$\begin{array}{l}\text { Other } \\
\text { minerals in } \\
\text { (T.S) }\end{array}$}} \\
\hline & $\begin{array}{l}\text { UAE } \\
\text { EPA } \\
1993\end{array}$ & $\begin{array}{c}\text { EU } \\
\text { EU } \\
2000\end{array}$ & $\begin{array}{c}\text { Turkey } \\
\text { DUWS } \\
2010\end{array}$ & $\begin{array}{c}\text { Present } \\
\text { study }\end{array}$ & & \\
\hline $\mathrm{Pb}$ & 840 & 1200 & 750 & 100.5 & $\mathrm{Al}$ & 55620 \\
\hline $\mathrm{Cd}$ & 85 & 40 & 10 & 2.2 & $\mathrm{Ca}$ & 38763 \\
\hline $\mathrm{Cr}$ & 3000 & 1000 & 1000 & 500.7 & $\mathrm{Fe}$ & 26376 \\
\hline $\mathrm{Cu}$ & 4300 & 1750 & 1000 & 163.2 & $\mathrm{Mg}$ & 20178 \\
\hline $\mathrm{Ni}$ & 420 & 400 & 300 & 64.5 & $\mathrm{~K}$ & 2812 \\
\hline $\mathrm{Zn}$ & 7500 & 4000 & 2500 & 515.6 & & \\
\hline $\mathrm{Hg}$ & 57 & 25 & 10 & 7.89 & & \\
\hline
\end{tabular}

\section{Experimental work}

According to (ASTM D4318), Atterberg limits were carried out on soils with different amounts of textile sludge [13]. Single consolidation tests were carried out on dry samples according to (ASTM D5333) [14], Samples were compacted by a hammer designed at the laboratory Fig. 4.

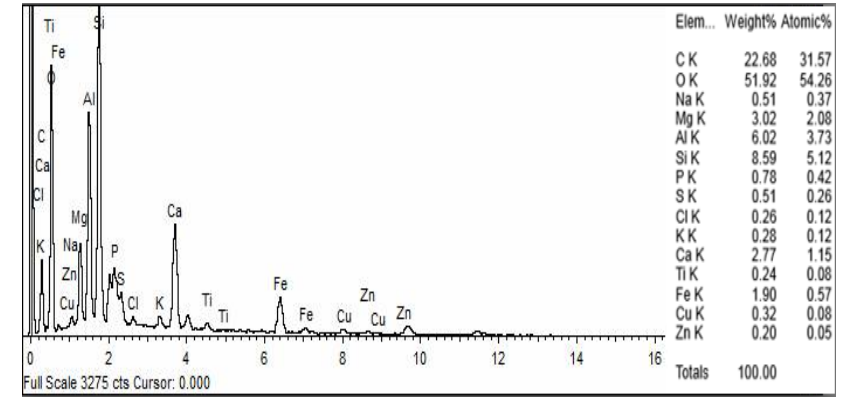

Fig. 3. EDAX analysis of textile sludge

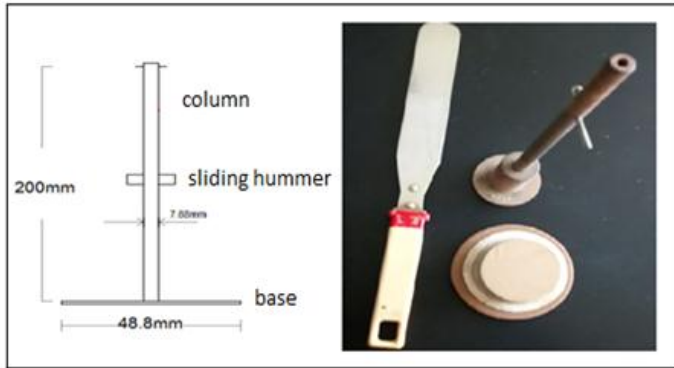

Fig. 4 Compaction equipment according to (Abbeche et al, 2010)

Table 3. Classification of Collapse potential (ASTM D5333)

\begin{tabular}{|c|c|}
\hline Degree of Collapse & $\begin{array}{c}\text { Collapse potential } \\
(\%)\end{array}$ \\
\hline None & 0 \\
\hline Slight & 0.1 to 2.0 \\
\hline Moderate & 2.1 to 6.0 \\
\hline Moderately severe & 6.1 to 10.0 \\
\hline Severe & $>10$ \\
\hline
\end{tabular}

Based on (Abbeche et al, 2010) collapse tests were carried out with various compaction energy at (20, 40 and 60 drops) and various water content (2, 4, and 6\%) [15]; in this study, all samples were dry and have the same compaction energy at (20 drops ) The test was conducted on collapsible soil and samples mixed with textile sludge to observe the effect of textile sludge on the collapse potential and the degree of collapse severity is determined according to Table .3 .

Direct shear tests were performed on the soil samples according to (ASTM D 3080)[16] at the following vertical pressures; 100,200 , and $300 \mathrm{kPa}$ All samples have the same compaction energy at 20 drops and compacted to obtain samples with a unit weight equal to $75 \%$ of maximum dry density. Tests were carried out on dry and saturated samples.

The modified compaction test (ASTM D1557) was performed to determine the maximum dry density (MDD) and optimum moisture content (OMC), using a modified compaction procedure [17]. California Bearing Ratio test (CBR) was performed according to (ASTM, 1883) at optimum moisture content and maximum dry density using a modified proctor effort and samples were soaked for $96 \mathrm{hrs}$ before test [18]

\section{A. Atterberg limits}

\section{Results AND DISCUSSIONS}

Soil and soil-sludge samples are found to have no plastic limit, while liquid limit increases from $30 \%$ to $41 \%$ at $24 \%$ textile sludge dosage and this may be due to the high potential of sludge in water absorption. 


\section{B. Single Oedometer test}

The results of single oedometer tests are shown in Fig. 5 and Table 4. Coefficient of collapse potential (CP) decreases from $11 \%$ to $2.6 \%$ at $24 \%$ textile sludge, this reduction may by as a result of the reaction between soil and the following oxides in textile sludge $\left(\mathrm{SiO}_{2}, \mathrm{Al}_{2} \mathrm{O}_{3}, \mathrm{MgO} \mathrm{CaO}\right.$, and $\left.\mathrm{Fe}_{2} \mathrm{O}_{3}\right)$ which are the basic oxides for creating a pozzolanic reaction. Fig. 6 shows untreated soil sample and soil with $24 \%$ sludge after saturation, the settlement of untreated soil sample with cracks is very clear in Fig. 6a.

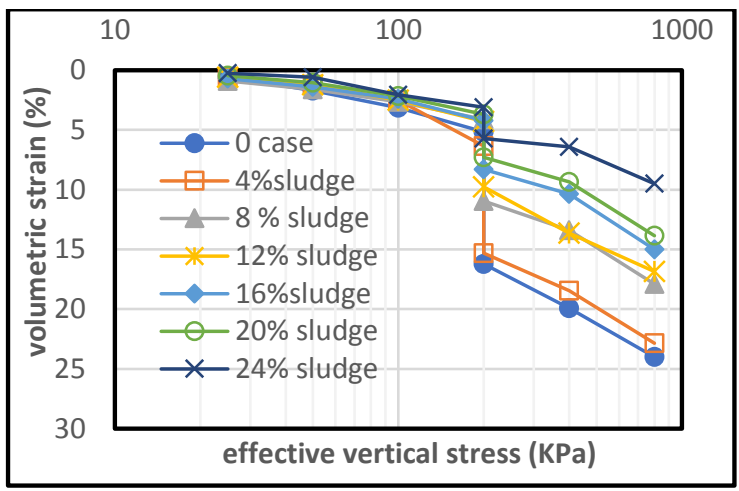

Fig. 5. Collapsible tests results for different textile sludge concentration

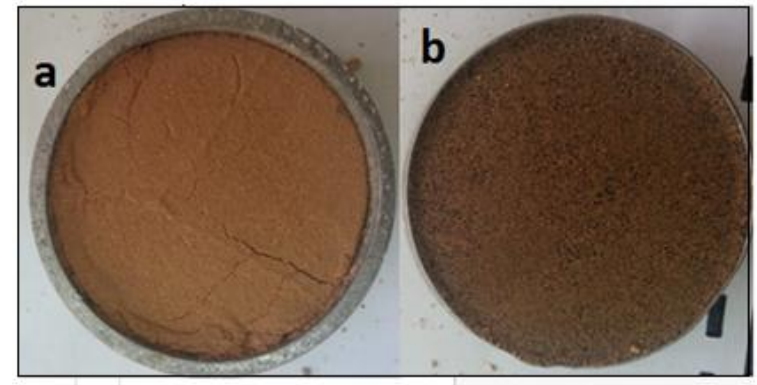

Fig. 6. Samples after saturation: (a) collapsible soil, (b) soil $+24 \%$ sludge

Table 4. Collapse potential corresponding to textile sludge

\begin{tabular}{|c|c|c|c|c|c|c|c|}
\hline $\begin{array}{c}\text { T.S } \\
(\%)\end{array}$ & 0 & 4 & 8 & 12 & 12 & 20 & 24 \\
\hline $\begin{array}{c}\text { C.P } \\
(\%)\end{array}$ & 11 & 8.95 & 6.35 & 5.45 & 4.1 & 3.6 & 2.63 \\
\hline
\end{tabular}

\section{Modified compaction results}

The modified proctor compaction tests are shown in Fig. 7. Table .5 presents the optimum parameters of proctor test. Optimum moisture content (OMC) increased from $12.27 \%$ to $24.65 \%$ at $24 \%$ textile sludge; this may be due to increasing fines that need extra water demand for hydration process. Maximum dry density decreased from $19.01 \mathrm{KN} / \mathrm{m} 3$ to 15.48 $\mathrm{KN} / \mathrm{m} 3$ at $24 \%$ textile sludge, this decrease may be attributed to replacement soil with a lower density material where the specific gravity and dry density of textile sludge is less than the specific gravity and dry density of collapsible soil.

\section{California bearing ratio results $(C B R)$}

Fig. 8 presents the curves of CBR tests as a relation between penetration in $(\mathrm{mm})$ and penetration stress in $(\mathrm{KPa})$, the relation between CBR value and textile sludge percentages is shown in Fig. 9. CBR value was decreased from 20.6 for collapsible soil to 12.9 for soil mixed with $24 \%$ textile sludge and the decrease rate in CBR value is less at textile sludge percentage greater than $12 \%$. The obtained CBR values in Table .6 were compared with the Egyptian specification limits of CBR values for each pavement layer Table .7 [19], and it could be concluded that subgrade is the suitable pavement layer for using textile sludge with soil up to $24 \%$.

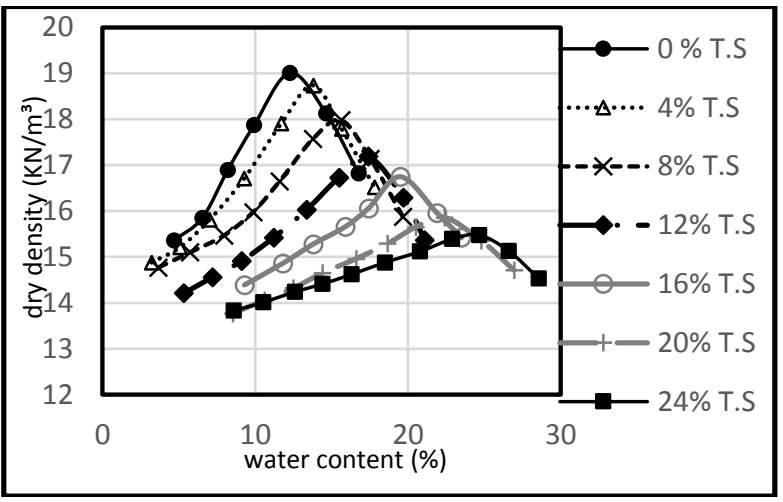

Fig. 7. Compaction curves for soil and sludge mixtures

Table 5. Influence of textile sludge on optimum parameters of proctor test

\begin{tabular}{|c|c|c|}
\hline T.S \% & O.M.C (\%) & M.D.D (KN/m3) \\
\hline 0 & 12.27 & 19.01 \\
\hline 4 & 13.79 & 18.74 \\
\hline 8 & 15.63 & 17.98 \\
\hline 12 & 17.4 & 17.19 \\
\hline 16 & 19.5 & 16.75 \\
\hline 20 & 22.39 & 15.86 \\
\hline 24 & 24.65 & 15.48 \\
\hline
\end{tabular}

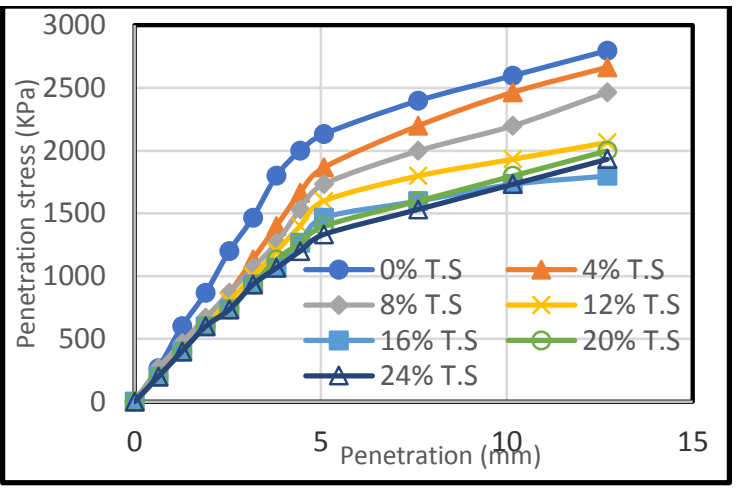

Fig. 8 CBR test results

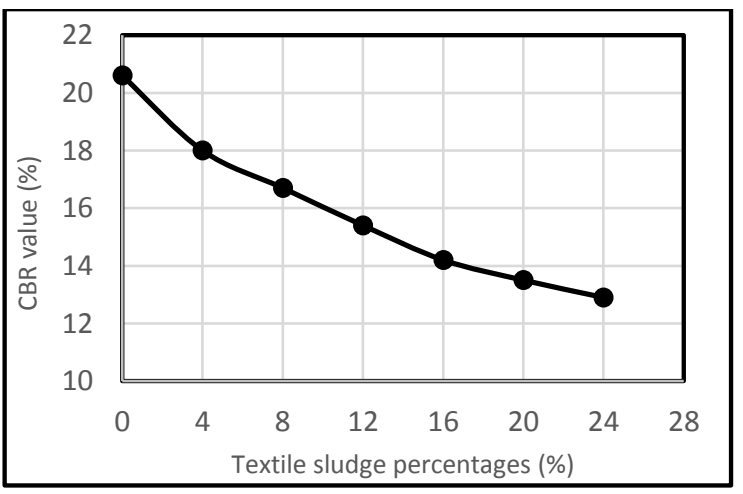

Fig. 9 CBR value versus T.S dosage

Table 6. Influence of textile sludge on CBR values 


\begin{tabular}{|c|c|}
\hline T.S \% & CBR (\%) \\
\hline 0 & 20.6 \\
\hline 4 & 18 \\
\hline 8 & 16.7 \\
\hline 12 & 15.4 \\
\hline 16 & 14.2 \\
\hline 20 & 13.5 \\
\hline 24 & 12.9 \\
\hline
\end{tabular}

Table 7. CBR values and the suitable use according to Egyptian specification

\begin{tabular}{|c|c|c|c|c|}
\hline \multirow{2}{*}{$\begin{array}{c}\text { CBR } \\
\text { value } \\
(\%)\end{array}$} & \multicolumn{2}{|c|}{ Egyptian specification of roads } & Present \\
\cline { 2 - 4 } & base & Subbase & Subgrade & \\
\cline { 2 - 4 } & $60 \%$ & $25 \%$ & $10-20 \%$ & $\begin{array}{c}(12.9- \\
20.6 \%)\end{array}$ \\
\hline
\end{tabular}

\section{E. Direct shear results}

The shear strength parameters, the cohesion (c) and the angle of internal friction $(\phi)$ are mentioned with respect to textile sludge dosage in Table 8, and presented in the form of histogram in Fig. 10 and Fig. 11 at dry and saturated case respectively. The cohesion values increases and the angle of internal friction values decreases. The cohesion increase may be due to the high concentration of the minerals existing in textile sludge such as Aluminum, Calcium, and Magnesium as described before in Table 2, this minerals form a cementation bonds between soil particles, In addition, a decrease in the friction angle can be explained by the growth of the cohesive admixtures [20, 21] Also the reduction of maximum dry density has a role in decreasing friction angle and consequently the soil bearing capacity.

Table 8. Influence of textile sludge on shear strength parameter

\begin{tabular}{|c|c|c|c|c|}
\hline \multirow{2}{*}{ T.S (\%) } & \multicolumn{2}{|c|}{$\begin{array}{c}\text { Cohesion } \\
\text { (KPa) }\end{array}$} & \multicolumn{2}{|c|}{$\begin{array}{c}\text { Friction angle, } \\
\phi\left(^{\circ}\right)\end{array}$} \\
\hline & dry & wet & dry & wet \\
\hline 0 & 29.3 & 32.1 & 27.609 & 26.15 \\
\hline 4 & 29.55 & 33.3 & 26.816 & 24.6 \\
\hline 8 & 32 & 33.7 & 26.793 & 24.1 \\
\hline 12 & 32.6 & 34.9 & 26.62 & 23.94 \\
\hline 16 & 33.1 & 35.3 & 25.45 & 23.17 \\
\hline 20 & 39.3 & 41 & 24.37 & 22.78 \\
\hline 24 & 41 & 41.9 & 21.8 & 20.5 \\
\hline
\end{tabular}

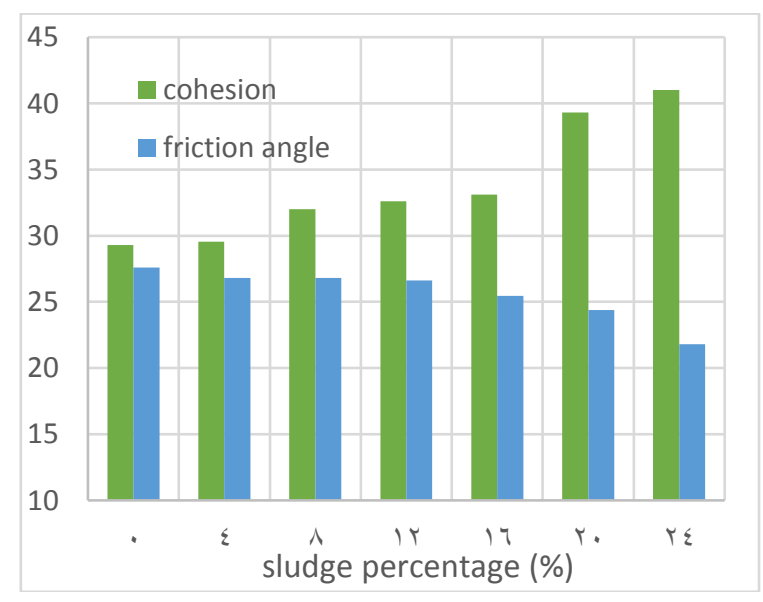

Fig. 10 Textile sludge effect on cohesion and internal friction angle at dry case

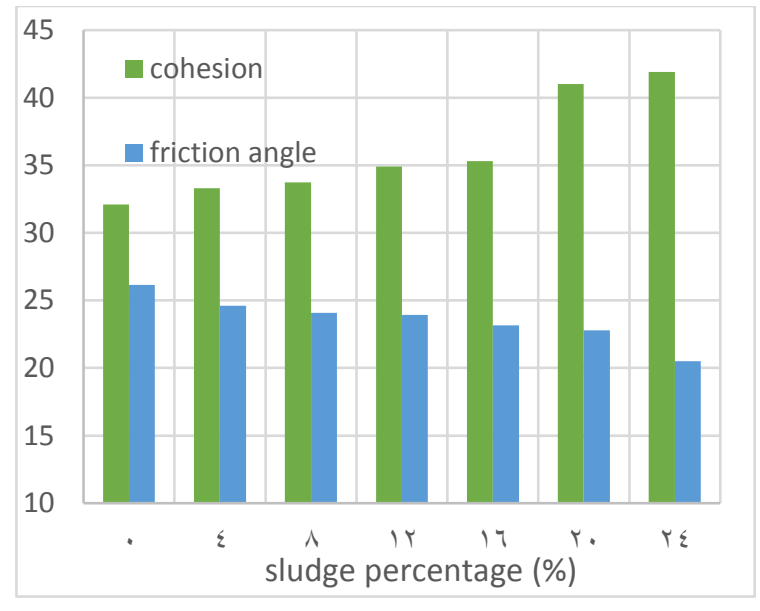

Fig. 11 Textile sludge effect on cohesion and internal friction angle at saturated case

\section{CONCLUSION}

In this research, collapsible soil was treated with different percentages of textile sludge in order to enhance their mechanical and physical characteristics and to reduce the collapse problem. The interpretation of the results of this study could be summarized in the following conclusions:

1) The inductivity coupled plasma test (ICP) indicated that the ratio of heavy metals in the textile sludge is within the permissible limits and therefore it can be used in soil treatment and thus we have provided an economical stabilizer for soil treatment and we have preserved the environment from the damage of sludge in case of keeping it without reuse.

2) An increase in liquid limit from $30 \%$ to $41 \%$, and all samples have no plastic limits

3) Single oedometer tests showed a decrease in collapse potential with increasing the amount of textile sludge. The reduction was about $76.36 \%$ when the soil was mixed with $24 \%$ sludge and degree of collapsibility changed from sever to moderate

4) Compaction results showed an increase in OMC and decrease in MDD

5) CBR values decreased from $20.6 \%$ to $12.9 \%$ and according to Egyptian specification of roads, soil-sludge mixtures could be used as a subgrade material in road way.

6) Direct shear results in dry and saturated case showed an increase in cohesion and decrease in friction angle with the increase of the percentage of mixed textile sludge

\section{REFERENCES}

[1]
J. H. Dudley, "REVIEW OF COLLAPSING SOILS," J. Soil Mech. Found. Div, vol. 96, no. 3, pp. 925-947, 1970.

K. E. Gaaver, "Geotechnical properties of Egyptian collapsible soils," Alexandria Eng. J., vol. 51, no. 3, pp. 205-210, 2012.

A. A. AL-Rawas, "State-of-the-Art-Review of Collapsible Soils," Sultan Qaboos Univ. J. Sci. [SQUJS], vol. 5, pp. 115-135, 2000.

I. Jefferson, D. Evstatiev, and D. Karastanev, "The treatment of collapsible loess soils using cement materials," Geotech. Spec. Publ., no. 178 , pp. $662-669,2008$

P. N. V. Jayanthi and D. N. Singh, "Utilization of Sustainable Materials for Soil Stabilization: State-of-the-Art," Adv. Civ. Eng. Mater., vol. 5, no. 1, pp. 46-79, 2016. 

plant sludge as brick material," J. Mater. Cycles Waste Manag., vol. 15, no. 4, pp. 564-570, 2013.

[7] S. Jeevanandam, K. Ravikumar, A. Das, and M. Goel, "Comprehensive Study on Textile Dyeing Sludge as a Substitute for Cement in Cement-Mortar," Int. J. Technol. July-December, vol. 5, no. 2, pp. 219-224, 2015.

[8] L. C. S. Herek, C. E. Hori, M. H. M. Reis, N. D. Mora, C. R. G. Tavares, and R. Bergamasco, "Characterization of ceramic bricks incorporated with textile laundry sludge," Ceram. Int., vol. 38, no. 2, pp. 951-959, 2012.

[9] A. K. Guha, M. T. Ahmed, S. Dey, and A. B. M. Foisal, "Construction of Roadway, Sanitary Latrine Ring and Septic Tank Using Textile Sludge," Resour. Environ., vol. 6, no. 2, pp. 28-40, 2016.

[10] A. G. de Oliveira, A. D. Barros, L. C. de F. L. Lucena, A. E. de F. L. Lucena, and J. D. Patricio, "Evaluation of calcined textile sludge as a stabilizing material for highway soil," J. Traffic Transp. Eng. (English Ed., 2020.

[11] H. Güllü and S. Girisken, "Performance of fine-grained soil treated with industrial wastewater sludge," Environ. Earth Sci., vol. 70, no. 2, pp. 777-788, 2013.

[12] S. A. Amiralian, M. A. Budihardjo, A. Chegenizadeh, and H. Nikraz, "Study of scale effect on strength characteristic of stabilised composite with sewage sludge - Part A: Preliminary study," Constr. Build. Mater., vol. 80, pp. 339-345, 2015.

[13] ASTM D4318, "Standard Test Methods for Liquid Limit, Plastic Limit, and Plasticity Index of Soils," Report, vol. 04, no. March 2010, pp. 1-14, 2005.

[14] ASTM International, "ASTM D5333-03: Standard Test Method for Measurement of Collapse Potential of Soils (Withdrawn 2012)," vol. 04, pp. 1-4, 2003.

[15] K. Abbeche, O. Bahloul, T. Ayadat, and A. Bahloul, "Treatment of collapsible soils by salts using the double consolidation method," Geotech. Spec. Publ., no. 202 GSP, pp. 69-78, 2010.

[16] ASTM D 3080-03, "Standard test method for direct shear test of soils under consolidated drained conditions," Anпи. B. ASTM Stand., vol. 04, no. April, pp. 347-352, 2003.

[17] ASTM International, "Standard Test Methods for Laboratory Compaction Characteristics of Soil Using," ASTM Stand. Guid., vol. 3, pp. 1-10, 2003

[18] D. ASTM, "Standard test method for CBR (California Bearing Ratio) of laboratory-compacted soils Annu," B. ASTM Stand, vol. 4, 1883.

[19] K. Sharobim, N. A. Hussein, M. Marzouk, and M. El-Mansy, "Assessment of Recycled Concrete aggregates as an Aggregate for Roads," Port-Said Eng. Res. J., vol. 21, no. 1, pp. 41-48, 2017.

[20] S. Bellil, K. Abbeche, and O. Bahloul, "Treatment of a collapsible soil using a bentonite-cement mixture," Stud. Geotech. Mech., vol. 40, no. 4, pp. 233-243, 2018.

[21] M. eldin M. A. Elmashad, "Improving the geotechnical behavior of sand through cohesive admixtures," Water Sci., vol. 32, no. 1, pp. 67$78,2018$. 